\title{
Surgical Treatment for Esophageal Cancer
}

\section{Current Issues}

\author{
Hiroyuki Kato Minoru Fukuchi Tatsuya Miyazaki Masanobu Nakajima Naritaka Tanaka \\ Takanori Inose Hitoshi Kimura Ahmad Faried Kana Saito Makoto Sohda Yasuyuki Fukai \\ Norihiro Masuda Ryokuhei Manda Hitoshi Ojima Katsuhiko Tsukada Hiroyuki Kuwano \\ Department of General Surgical Science (Surgery I), Gunma University, Graduate School of Medicine, \\ Maebashi, Japan
}

\section{Key Words}

Esophageal cancer $\cdot$ Neoadjuvant therapy $\cdot$ Salvage

treatment $\cdot$ Chemoradiotherapy $\cdot$ Minimally invasive surgery

\begin{abstract}
Esophageal cancer is one of the most difficult malignancies to cure. The prognosis remains unsatisfactory despite significant advances in surgical techniques and perioperative management. The optimal treatment strategy for localized esophageal cancer has not yet been established. Surgical resection remains the mainstay of treatment for esophageal cancer, and curative resection is the most important surgery. Extended esophagectomy with three-field lymphadenectomy provides the highest quality of tumor clearance and prolongation of patient survival. There has been intense effort in developing novel strategies to treat patients with resectable esophageal cancer. Various combined-modality approaches have been attempted to improve treatment outcomes. Definitive chemoradiotherapy has an impact on long-term survival in patients with resectable esophageal cancer. Accordingly, there are three main combined-modality approaches: esophagectomy with adjuvant chemotherapy or chemoradiotherapy; primary definitive chemoradiotherapy with or without salvage esophagectomy, and preoperative chemoradiotherapy followed by planned
\end{abstract}

esophagectomy. Recently, owing to the remarkable advances in optical technology, minimally invasive esophagectomy using endoscopic instruments has been introduced into esophageal cancer surgery. This article reviews recent changes in the treatment of esophageal cancer surgery, and considers the role of esophagectomy.

Copyright $\odot 2007$ S. Karger AG, Basel

\section{Introduction}

Esophageal cancer is one of the least studied and deadliest cancers worldwide. During the last three decades, important changes have occurred in the epidemiologic patterns of this disease. The most striking has been the dramatic rise in the West of the incidence of adenocarcinoma of the lower esophagus and cardia, which has surpassed squamous cell cancer as the predominant cell type [1-3]. In Asia, however, diagnosed esophageal cancers are predominantly squamous cell in type and are mostly located in the middle third of the esophagus. There has not been a noticeable rise in the incidence of adenocarcinoma of the esophagus and gastric cardia in published Asian data. Recent advances in the diagnosis, staging, and treatment of this neoplastic condition have led to small but significant improvements in survival.

\section{KARGER}

Fax +41613061234 E-Mail karger@karger.ch www.karger.com
(C) 2007 S. Karger AG, Basel

0253-4886/07/0242-0088\$23.50/0

Accessible online at:

www.karger.com/dsu
Hiroyuki Kato, MD, Department of General Surgical Science (Surgery I)

Gunma University Graduate School of Medicine

3-39-22, Showa-machi, Maebashi 371-8511 (Japan)

Tel. +81 27220 8224, Fax +81 272208230

E-Mail hiroyuki@po.wind.ne.jp 
Esophageal cancer is one of the most difficult malignancies to cure [4]; the prognosis remains unsatisfactory despite significant advances in surgical techniques and perioperative management [5]. The optimal management of esophageal cancer remains controversial. While surgery is the mainstay of treatment, the incorporation of chemotherapy and/or radiotherapy suggests that a combined-modality approach is worthy of further investigation. Recently, owing to remarkable advances in optical technology, minimally invasive esophagectomy using endoscopic instruments has been introduced into esophageal cancer surgery. Furthermore, definitive chemoradiotherapy has an impact on long-term survival in patients with resectable esophageal cancer. Salvage esophagectomy is undertaken for recurrence or residual tumor after definitive chemoradiotherapy.

This article reviews the recent changes in the treatment of esophageal cancer surgery, and considers the role of esophagectomy.

\section{Esophageal Resection}

Esophageal cancer is a challenging disease that often has a poor outcome. Esophagectomy followed by reconstruction surgery has been the most reliable modality for cure in patients without evidence of disease spread. The three most common techniques for esophagectomy are the transhiatal approach, the Ivor Lewis esophagectomy (right thoracotomy and laparotomy), and the McKeown technique (right thoracotomy followed by laparotomy and neck incision with cervical anastomosis) [4]. There have been several small, underpowered randomized trials comparing transhiatal esophagectomy with standard transthoracic esophagectomy, but none have shown important differences between the two approaches $[6,7]$. In a meta-analysis by Hulscher et al. [8], the 5-year survival was approximately $20 \%$ after both transthoracic and transhiatal resection, though transthoracic resection was associated with significantly higher early morbidity and mortality. In contrast, Hagen et al. [9] demonstrated significantly better survival ( 41 vs. $14 \%$; $p<0.001$ ) in 30 patients who underwent en bloc esophagectomy compared with 39 patients who underwent transhiatal esophagectomy. They claimed the superiority of extended en bloc esophagectomy over transhiatal resection for carcinoma of the lower esophagus and cardia. There have been three randomized clinical trials comparing transthoracic esophagectomy with transhiatal esophagectomy [10-12]. All of these randomized clinical trials failed to detect any
Table 1. Comparative studies between two-field and three-field lymphadenectomy

\begin{tabular}{lcclll}
\hline Reference & Procedure & $\begin{array}{l}\text { Number } \\
\text { of patients }\end{array}$ & $\begin{array}{l}\text { Tumor } \\
\text { histology }\end{array}$ & $\begin{array}{l}\text { 5-year } \\
\text { OS, } \%\end{array}$ & $\begin{array}{l}\text { Survival } \\
\text { difference }\end{array}$ \\
\hline $\begin{array}{l}\text { Kato } \\
\text { et al. [13] }\end{array}$ & TTE (3F) & 77 & SC & 49 & $\mathrm{p}<0.01$ \\
\hline Tsono (2F) & 73 & SC & 34 & \\
et al. [15] & TTE (3F) & 1,740 & SC & 34 & $\mathrm{p}<0.001$ \\
\hline Akiyama & TTE (3F) & 2,671 & SC & 27 & \\
et al. [14] & TTE (2F) & 283 & SC & 55 & $\mathrm{p}<0.01$ \\
\hline $\begin{array}{l}\text { Fujita } \\
\text { et al. [16] }\end{array}$ & TTE (3F) & 63 & SC & 40 & NS \\
\hline
\end{tabular}

TTE = Transthoracic esophagectomy; $3 \mathrm{~F}=$ three-field; $2 \mathrm{~F}=$ two-field; SC = squamous cell carcinoma; NS = not significant; OS = overall survival.

significant differences in patient survival between the two procedures. The randomized study by Hulscher et al. [12] compared 106 patients who underwent transhiatal esophagectomy and 114 who underwent transthoracic esophagectomy for adenocarcinoma of the esophagus and cardia. Transhiatal esophagectomy was associated with lower morbidity than transthoracic esophagectomy with extended en bloc lymphadenectomy. Although median overall, disease-free, and quality-adjusted survival did not differ statistically between the groups, there was a trend toward improved long-term survival at 5 years with the extended transthoracic approach.

Most of the data on more aggressive surgery are coming from Asia, in particular from Japan. The 5-year survival after esophagectomy with three-field lymph node dissection was reported to be $48.7 \%$ by Kato et al. [13] and $55.0 \%$ by Akiyama et al. [14] (table 1). Kato et al. [13] compared two-field with three-field lymphadenectomy for squamous cell carcinoma of the esophagus. The 5year survival was $48.7 \%$ in three-field lymphadenectomy and $33.7 \%$ in two-field lymphadenectomy. A major criticism of this study, however, was the difference in patient characteristics. In a nationwide study reported by Isono et al. [15], patient survival was significantly better after three-field lymphadenectomy than after conventional two-field lymphadenectomy. Likewise, Fujita et al. [16] reported the survival of patients undergoing three-field lymphadenectomy to be significantly better than that with two-field lymphadenectomy $(\mathrm{p}<0.05)$ in patients with carcinoma in the upper thoracic or mid-thoracic 
esophagus with metastasis in the lymph nodes. However, the mortality, morbidity, and postoperative quality of life did not differ between the two procedures [16]. Approximately 80 lymph nodes or more are commonly removed and the reported 5-year survival rates are $40-60 \%$ after this procedure [17-21]. Tabira et al. [22] concluded that three-field dissection should be indicated for patients with metastases in 1-4 lymph nodes. Shiozaki et al. [23] reported that cervical lymphadenectomy could be omitted for patients with cancer in the middle or lower thoracic esophagus when no metastasis was found in the recurrent nerve nodes. The efficacy of three-field lymphadenectomy for improving the survival of patients with esophageal cancer has also been demonstrated by Lerut et al. [24] and Altorki et al. [25]. Many Japanese studies have subsequently reported a benefit of three-field lymphadenectomy [26-29].

\section{Minimally Invasive Surgery}

Transthoracic surgery for esophageal cancer is associated with a high incidence of pulmonary complications. The recent development of minimally invasive esophagectomy using a thoracoscopic approach may have the potential to minimize morbidity and mortality. One strategy to reduce surgical invasiveness is to perform radical esophagectomy via thoracoscopy rather than as an open procedure. In 1992, Cuschieri et al. [30] described their initial experience with a small series of patients with esophageal cancer in whom resection of the esophagus and mediastinal lymphadenectomy were performed through a right thoracoscopic approach. Since then, the results of thoracoscopic esophagectomy have been reported by a number of centers. Many have described the feasibility of the technique, and a few have reported an advantage over open surgery. However, initial results with the thoracoscopic approach did not show a real benefit over the open approach, in particular due to a high number of pulmonary complications [31-37].

Despite these reports of there being no real advantages to the thoracoscopic approach for esophageal resection, Japanese centers gave it a new impetus. In 1996, Akaishi et al. [38] performed en bloc total esophagectomy with radical lymphadenectomy by right thoracoscopy in 39 patients with esophageal cancer, with the rest of the operation carried out by conventional means. The operating time was $200 \pm 41 \mathrm{~min}$, blood loss was $270 \pm 157$ $\mathrm{ml}$, and $19.7 \pm 11$ lymph nodes were harvested. No deaths occurred, and 22 of the 39 patients showed only a slight decrease in their vital capacity and did not require postoperative respiratory support. That the decline in pulmonary function was significantly less than in the open technique was an important result of this study [38]. Kawahara et al. [39] achieved similar results in their series of 23 patients. Osugi et al. [40] described their experience with three-field lymphadenectomy. They compared 77 patients with squamous cell cancer approached by mini-thoracotomy with a control group of 72 patients approached conventionally in a three-stage procedure. Their results in terms of retrieved lymph nodes (33 vs. 32 ), longer thoracic operation time (227 vs. $186 \mathrm{~min}$ ), less vital capacity reduction ( 15 vs. $22 \%, p=0.016)$, and similar 3 - and 5 -year survival rates (70 and 55 vs. 60 and $57 \%$, respectively) were remarkable. They clarified that thoracoscopic resection achieved results comparable to those of open radical esophagectomy, with less surgical trauma [40]. By comparing the outcomes of the first 34 patients operated on with the last 46 , this same Japanese group showed the importance of the learning curve in reducing operation time and achieving better outcomes with this approach. They found that the incidence of pulmonary complications with experience of the procedure was only $5 \%$. The last group showed significant reductions in blood loss, duration of thoracoscopy, and incidence of postoperative respiratory complications, and a greater number of retrieved lymph nodes [41]. The estimated risks in thoracoscopic resection appeared to be less after the first 20 cases. These results were confirmed by Taguchi et al. [42] and Smithers et al. [43] in Australia. They compared the results of spirometry and exercise tolerance between patients esophagectomized thoracoscopically and conventionally. Luketich et al. [44] reported an incidence of pneumonia of $7.7 \%$ in their study of $222 \mathrm{pa}-$ tients. They described their recent experience with these patients, most of whom underwent esophageal resection with thoracoscopy and laparoscopy. The most important contribution was that the median intensive care unit stay was 1 day and the total hospital stay was just 7 days, with an operative mortality of 1.4\% [44]. Quality-of-life scores were similar to the preoperative values and population norms. The results of Nguyen et al. [45] with 46 consecutive patients were concordant with those obtained by Luketich et al. [44]. Recent reports have indicated an advantage of the thoracoscopic procedure performed with robotic assistance, but the full role of robot-assisted esophageal resection remains to be better defined [46, 47].

Minimally invasive esophagectomy could be safely performed in selected cases. The overall benefits of tho- 
racoscopic esophagectomy tend to relate to the number of cases experienced. Thoracoscopic radical esophagectomy could be performed thoracoscopically with beneficial outcomes by experienced surgeons. Because the efficacy improves with the operator's experience, satisfactory outcomes will be obtained only in centers performing a sufficient number of procedures to provide operators with the opportunity to refine the necessary skills. Moreover, these centers teach various surgical techniques to surgeons, and some randomized protocols are being designed to compare not only the short- but also the longterm oncologic outcomes of minimally invasive approaches with those of conventional techniques $[48,49]$.

\section{Combined-Modality Treatment}

\section{Neoadjuvant Chemotherapy}

To improve surgical outcome, preoperative chemotherapy has been investigated compared with surgery alone in randomized trials, though the results of these studies are controversial. Three meta-analysis based on these randomized trials have been published [50-52]. There was no difference in survival rate in the meta-analysis in which the end point was 1-year survival in six randomized trials [50]. In contrast, the 2-year survival was increased with preoperative chemotherapy by $4.4 \% \mathrm{com}$ pared with surgery alone in the meta-analysis in which the end point was 2-year survival in seven randomized trials [51]. If this meta-analysis was limited to four recent randomized trials using cisplatin and 5-fluorouracil (5FU) for chemotherapy, it was shown that the 2-year survival rose by $6.3 \%$. However, an improved survival rate with preoperative chemotherapy was not shown in another meta-analysis in which the end point was 2-year survival [52]. The effect of preoperative chemotherapy is unclear at this time.

\section{Neoadjuvant Chemoradiotherapy}

Preoperative chemoradiotherapy was undertaken in the latter half of the 1980s in Europe and America. In some randomized trials, it has been verified that preoperative chemoradiotherapy improves the survival rate of esophageal cancer patients. Although comparatively few centers perform preoperative chemoradiotherapy because of the high-quality surgical treatment available in Japan, one randomized trial report has shown that hyperthermochemoradiotherapy was effective in the local control of esophageal cancer [53]. There are five meta-analyses based on five to seven randomized trials comparing preoperative chemoradiotherapy followed by surgery with surgery alone. The survival rate with preoperative chemoradiotherapy was not improved in the meta-analysis in which the end point was 1- or 2-year survival [50, 51]. In two meta-analyses in which the end point was 3year survival, preoperative chemoradiotherapy (20-45 Gy) for resectable disease significantly increased the operation-related mortality within 90 days after surgery; however, the rate of local recurrences was decreased and 3 -year survival was significantly improved compared with surgery alone $[54,55]$. Preoperative chemoradiotherapy decreased the risk of death by $14 \%$ in the metaanalysis in which the end point was the hazard ratio of the survival rate curve [56]. In five reports [57-61] of six randomized trials in this meta-analysis, the survival rate of the preoperative chemoradiotherapy group was higher than that of surgery alone, but not significantly so. In the other report, which was directed only toward esophageal adenocarcinoma, the survival rate of the preoperative chemoradiotherapy group was significantly higher than that of surgery alone [62] (table 2). In the randomized trial reported from Australia in 2005, the disease-free survival rate of the preoperative chemoradiotherapy group was significantly higher than that of surgery alone if the population was limited to those with squamous cell carcinoma [63], but the difference according to histological type does not always correspond between reports. Preoperative chemoradiotherapy is a combined therapy that can improve long-term survival after the 3rd year following surgery. However, there are no grounds to recommend preoperative chemoradiotherapy as a preoperative treatment because there is no randomized trial of this modality in Japan.

\section{Adjuvant Chemotherapy}

A randomized trial of postoperative chemotherapy in esophageal squamous cell carcinoma was performed by the Japan Clinical Oncology Group (JCOG) in 1992 [64]. This trial compared surgery alone $(n=100)$ and postoperative chemotherapy groups ( $\mathrm{n}=122$; JCOG9204); the postoperative chemotherapy involved two courses of cisplatin $\left(80 \mathrm{mg} / \mathrm{m}^{2}\right.$, day 1$)$ and $5 \mathrm{FU}\left(800 \mathrm{mg} / \mathrm{m}^{2}, 5\right.$ days $)$. In this study, no significant difference was observed in the survival rate, but a significant difference was observed in the disease-free survival rate ( $43 \%$ in surgery alone arm vs. $58 \%$ in postoperative chemotherapy arm) [64]. Furthermore, this study reported that postoperative chemotherapy was especially useful for patients with lymph node metastases. In contrast, the effect of postoperative chemotherapy on survival rate was not significant 
Table 2. Randomized trials comparing chemoradiotherapy followed by surgery with surgery alone

\begin{tabular}{|c|c|c|c|c|c|c|c|}
\hline Regimen & $\begin{array}{l}\text { Radiation } \\
\text { Gy }\end{array}$ & $\begin{array}{l}\text { Number } \\
\text { of patients }\end{array}$ & $\begin{array}{l}\text { Resect- } \\
\text { ability, \% }\end{array}$ & $\begin{array}{l}\text { Pathologic } \\
\text { CR, \% }\end{array}$ & $\begin{array}{l}\text { Survival } \\
\%\end{array}$ & $\mathrm{p}$ value & Reference \\
\hline $\begin{array}{l}\text { CDDP+5FU } \\
\text { Surgery alone }\end{array}$ & 45 & $\begin{array}{l}50 \\
50\end{array}$ & $\begin{array}{r}94 \\
100\end{array}$ & 28 & $\begin{array}{l}30 \\
16\end{array}$ & NS & Urba et al. [57] \\
\hline $\begin{array}{l}\text { CDDP+5FU } \\
\text { Surgery alone }\end{array}$ & 37 & $\begin{array}{l}143 \\
139\end{array}$ & $\begin{array}{l}96.5 \\
98.6\end{array}$ & 26 & $\begin{array}{l}37 \\
35\end{array}$ & NS & Bosset et al. [58] \\
\hline $\begin{array}{l}\mathrm{CDDP}+5 \mathrm{FU} \\
\text { Surgery alone }\end{array}$ & 20 & $\begin{array}{l}41 \\
45\end{array}$ & $\begin{array}{l}85 \\
93\end{array}$ & 10 & $\begin{array}{l}19.2 \\
13.8\end{array}$ & NS & Le Prise et al. [59] \\
\hline $\begin{array}{l}\text { CDDP+5FU } \\
\text { Surgery alone }\end{array}$ & 45 & $\begin{array}{l}35 \\
34\end{array}$ & $\begin{array}{l}73.4 \\
100\end{array}$ & - & $\begin{array}{l}26 \\
20\end{array}$ & NS & Apinop et al. [60] \\
\hline $\begin{array}{l}\text { CDDP+BLM } \\
\text { Surgery alone }\end{array}$ & 35 & $\begin{array}{l}53 \\
50\end{array}$ & $\begin{array}{l}88.7 \\
82.0\end{array}$ & - & $\begin{array}{r}17 \\
9\end{array}$ & NS & Nygaard et al. [61] \\
\hline $\begin{array}{l}\text { CDDP+5FU } \\
\text { Surgery alone }\end{array}$ & 40 & $\begin{array}{l}58 \\
55\end{array}$ & $\begin{array}{l}100 \\
100\end{array}$ & 25 & $\begin{array}{r}32 \\
6\end{array}$ & 0.01 & Walsh et al. [62] \\
\hline
\end{tabular}

$\mathrm{CDDP}=$ Cisplatin; $5 \mathrm{FU}=$ 5-fluorouracil $\mathrm{CR}=$ complete response; $\mathrm{NS}=$ not significant.

in a meta-analysis based on randomized trials in Europe and America [50]. There was no evidence that postoperative chemotherapy improved the survival rate after curative resection in esophageal cancer patients. However, the disease-free survival rate was significantly improved by postoperative chemotherapy in the randomized trial performed in Japan. Therefore, postoperative chemotherapy is thought to be effective in preventing recurrence after surgery.

\section{Adjuvant Radiotherapy}

There are four randomized trials comparing surgery alone and postoperative radiotherapy (45-65 Gy) [6568]. These reports showed no significant improvement in survival rate, though the local recurrence rate in the irradiated area was decreased by postoperative radiotherapy. In a meta-analysis based on these randomized trials, no significant improvement in survival rate with postoperative radiotherapy was observed. Therefore, postoperative radiotherapy is not considered a standard treatment [50].

\section{Salvage Esophagectomy}

Definitive chemoradiotherapy has recently been chosen more often as a first-line therapy for resectable esophageal cancer $[69,70]$. However, definitive chemoradio- therapy does not achieve a complete response (CR) in all esophageal cancers. Furthermore, even if CR has been attained, some tumors recur later $[69,71]$. Unfortunately, it is difficult to completely control a lesion with definitive chemoradiotherapy, and $40-60 \%$ of patients have persistent or relapsed tumor at the primary site within 1 year $[70,71]$. Salvage surgery is often required for these uncontrollable tumors.

Esophagectomy after chemoradiotherapy, whether planned or salvage, causes greater morbidity than primary esophagectomy [58, 72, 73]. Radiation damages mediastinal structures, and causes inflammation early (several weeks) and fibrosis later (several months). Tissue injury depends on the total radiation dose and the method of delivery. High total dose, large treatment fields, and large fractions cause more severe tissue injury $[58,71,72,74,75]$. There are also complications of esophagectomy after radiotherapy treatment; esophagogastric anastomotic leaks, adult respiratory distress syndrome, airway complications, and death are the most common [76-79]. Even specialized units report operative mortalities of over $10 \%$ for esophagectomy after chemoradiotherapy $[77,79]$. Salvage esophagectomy may cause even more morbidity than planned esophagectomy. Swisher et al. [80] described a series of patients treated with planned or salvage esophagectomy at the MD Anderson Cancer Center. Salvage esophagectomy patients had a significantly higher incidence of anastomotic leaks (39 
vs. $7 \%$; $p=0.005$ ) and longer hospital stay ( 29 vs. 18 days; $\mathrm{p}=0.03)$ than those treated with planned esophagectomy. The operative mortality was also higher (15 vs. $6 \%$; $\mathrm{p}=0.20)$, but this did not reach statistical significance [80].

Because salvage esophagectomy carries a high risk, it should be performed only in selected patients who are likely to benefit, namely those with isolated persistent or recurrent local malignant disease. Therefore, patients with systemic lymph node metastases must be excluded. Patients who meet the oncologic criteria for salvage esophagectomy need careful assessment of their fitness for surgery [81]. Chronic lung disease, poor performance status, and malnutrition are predictors of complications after standard esophagectomy [82-85]. Nakamura et al. [86] have said that vital capacity and albumin level in particular are important risk factors for complications after transthoracic esophagectomy [85, 87].

For persistence or recurrence after chemoradiotherapy, salvage surgery is important but carries a high risk. We must, therefore, consider adaptation carefully.

\section{Conclusion}

Esophageal cancer is one of the most difficult malignancies to cure. The optimal treatment strategy for localized esophageal cancer has not yet been established. Surgical resection remains the mainstay of treatment for esophageal cancer, and there has been intense effort to develop novel strategies for the treatment of patients with resectable esophageal cancer. Various combined-modality approaches have been attempted to improve treatment outcomes. There are three main combined-modality approaches: esophagectomy with adjuvant chemotherapy or chemoradiotherapy; primary definitive chemoradiotherapy with or without salvage esophagectomy, and preoperative chemoradiotherapy followed by planned esophagectomy. Furthermore, owing to the remarkable advances in optical technology, minimally invasive esophagectomy using endoscopic instruments has been introduced to esophageal cancer surgery. This article is a review of the recent changes in the treatment of esophageal cancer surgery, and considers the role of esophagectomy.

\section{References}

1 Law S, Wong J: Current management of esophageal cancer. J Gastrointest Surg 2005; 9:291-310.

$\checkmark 2$ Devesa SS, Blot WJ, Fraumeni JF Jr: Changing patterns in the incidence of esophageal and gastric carcinoma in the United States. Cancer 1998;83:2049-2053.

-3 Kuwano H, Kato H, Miyazaki T, Fukuchi M, Masuda N, Nakajima M, Fukai Y, Sohda M, Kimura H, Faried A: Genetic alterations in esophageal cancer. Surg Today 2005;35:718.

$\checkmark 4$ Wright CD: Esophageal cancer surgery in 2005. Minerva Chir 2005;60:431-444.

5 Enzinger PC, Mayer RJ: Esophageal cancer. N Engl J Med 2003;349:2241-2252.

-6 Pommier RF, Vetto JT, Ferris BL, Wilmarth TJ: Relationships between operative approaches and outcomes in esophageal cancer. Am J Surg 1998;175:422-425.

7 Rentz J, Bull D, Harpole D, et al: Transthoracic versus transhiatal esophagectomy: a prospective study of 945 patients. J Thorac Cardiovasc Surg 2003;125:1114-1120.

-8 Hulscher JBF, Tijssen JGP, Obertop H, van Lanschot JJB: Transthoracic versus transhiatal resection for carcinoma of the esophagus: a meta-analysis. Ann Thorac Surg 2001;72: 306-313.
9 Hagen JA, Peters JH, DeMeester TR: Superiority of extended en bloc esophagogastrectomy for carcinoma of the lower esophagus and cardia. J Thorac Cardiovasc Surg 1993; 106:850-858.

10 Goldminc M, Maddern G, Le Prise E, Meunier B, Campion JP, Launois B: Oesophagectomy by a transhiatal approach or thoracotomy: a prospective randomized trial. $\mathrm{Br} \mathrm{J}$ Surg 1993;80:367-370.

11 Chu KM, Law SY, Fok M, Wong J: A prospective randomized comparison of transhiatal and transthoracic resection for lower-third esophageal carcinoma. Am J Surg 1997;174: 320-324.

12 Hulscher JBF, van Sandick JW, Boer AGEM, et al: Extended transthoracic resection compared with limited transhiatal resection for adenocarcinoma of the esophagus. N Engl J Med 2002;347:1662-1669.

13 Kato H, Watanabe H, Tachimori Y, Iizuka T: Evaluation of neck lymph node dissection for thoracic esophageal carcinoma. Ann Thorac Surg 1991;51:931-935.

14 Akiyama H, Tsurumaru M, Udagawa H, Kajiyama Y: Radical lymph node dissection for cancer of the thoracic esophagus. Ann Surg 1994;220:364-373.

15 Isono K, Sato H, Nakayama K: Results of a nationwide study on the three-field lymph node dissection of esophageal cancer. Oncology 1991;48:411-420.
16 Fujita H, Kakegawa T, Yamana H, et al: Mortality and morbidity rates, postoperative course, quality of life, and prognosis after extended radical lymphadenectomy for esophageal cancer. Ann Surg 1995;222:654-662.

17 Baba M, Aikou T, Yoshinaka H, et al: Longterm results of subtotal esophagectomy with three-field lymphadenectomy for carcinoma of the thoracic esophagus. Ann Surg 1994; 219:310-316.

- 18 Matsubara T, Ueda M, Nagao N, Takahashi T, Nakajima T, Nishi M: Cervicothoracic approach for total mesoesophageal dissection in cancer of the thoracic esophagus. J Am Coll Surg 1998; 187:238-245.

19 Nishimaki T, Suzuki T, Suzuki S, Kuwabara S, Hatakeyama K: Outcomes of extended radical esophagectomy for thoracic esophageal cancer. J Am Coll Surg 1998;186:306312 .

20 Nishihira T, Hirayama K, Mori S: A prospective randomized trial of extended cervical and superior mediastinal lymphadenectomy for carcinoma of the thoracic esophagus. Am J Surg 1998;175:47-51.

21 Watanabe H, Kato H, Tachimori Y: Significance of extended systemic lymph node dissection for thoracic esophageal carcinoma in Japan. Recent Results Cancer Res 2000;155: 123-133. 
-22 Tabira Y, Kitamura N, Yoshioka M, Tanaka M, Nakano K, Toyota N, Mori T: Significance of three-field lymphadenectomy for carcinoma of the thoracic esophagus based on depth of tumor infiltration, lymph nodal involvement and survival rate. J Cardiovasc Surg (Torino) 1999;40:737-740.

-23 Shiozaki H, Yano M, Tsujinaka T, Inoue M, Tamura S, Doki Y, Yasuda T, Fujiwara Y, Monden M: Lymph node metastasis along the recurrent nerve chain is an indication for cervical lymph node dissection in thoracic esophageal cancer. Dis Esophagus 2001;14: 191-196.

24 Lerut T, Nafteux P, Moons J, Coosemans W, Decker G, De Leyn P, Van Raemdonck D, Ectors $\mathrm{N}$ : Three-field lymphadenectomy for carcinoma of the esophagus and gastroesophageal junction in $174 \mathrm{R} 0$ resections: impact on staging, disease-free survival, and outcome: a plea for adaptation of TNM classification in upper-half esophageal carcinoma. Ann Surg 2004;240:962-972.

-25 Altorki N, Kent M, Ferrara C, Port J: Threefield lymph node dissection for squamous cell and adenocarcinoma of the esophagus. Ann Surg 2002;236:177-183.

-26 Udagawa H, Akiyama H: Surgical treatment of esophageal cancer: Tokyo experience of the three-field technique. Dis Esophagus 2001;14:110-114.

-27 Shimada H, Okazumi S, Matsubara H, Nabeya Y, Shiratori T, Shimizu T, Shuto K, Hayashi H, Ochiai T: Impact of the number and extent of positive lymph nodes in 200 patients with thoracic esophageal squamous cell carcinoma after three-field lymph node dissection. World J Surg 2006;30:14411449.

-28 Fujita H, Sueyoshi S, Tanaka T, Fujii T, Toh U, Mine T, Sasahara H, Sudo T, Matono S, Yamana H, Shirouzu K: Optimal lymphadenectomy for squamous cell carcinoma in the thoracic esophagus: comparing the short- and long-term outcome among the four types of lymphadenectomy. World J Surg 2003;27:571-579.

-29 Tachibana M, Kinugasa S, Yoshimura H, Shibakita M, Tonomoto Y, Dhar DK, Nagasue N: Clinical outcomes of extended esophagectomy with three-field lymph node dissection for esophageal squamous cell carcinoma. Am J Surg 2005;189:98-109.

-30 Cuschieri A, Shimi S, Banting S: Endoscopic oesophagectomy through a right thoracoscopic approach. J R Coll Surg Edinb 1992; 37:7-11.

-31 Azagra JS, Ceuterick M, Goergen M, et al: Thoracoscopy in oesophagectomy for oesophageal cancer. Br J Surg 1993;80:320321.

-32 Gossot D, Fourquier P, Celerier M: Thoracoscopic esophagectomy: technique and initial results. Ann Thorac Surg 1993;56:667-670.
3 Collard JM, Lengele B, Otte JB, Kestens PJ: En bloc and standard esophagectomies by thoracoscopy. Ann Thorac Surg 1993;56: 675-679.

34 McAnena OJ, Rogers J, Williams NS: Right thoracoscopically assisted oesophagectomy for cancer. Br J Surg 1994;81:236-238.

35 Dexter SP, Martin IG, McMahon MJ: Radical thoracoscopic esophagectomy for cancer. Surg Endosc 1996;10:1113-1115.

36 Robertson GS, Lloyd DM, Wicks AC, Veitch PS: No obvious advantages for thoracoscopic two-stage oesophagectomy. Br J Surg 1996; 83:675-678.

37 Law S, Fok M, Chu KM, Wong J: Thoracoscopic esophagectomy for esophageal cancer. Surgery 1997;122:8-14.

38 Akaishi T, Kaneda I, Higuchi N, et al: Thoracoscopic en bloc total esophagectomy with radical mediastinal lymphadenectomy. J Thorac Cardiovasc Surg 1996;112:15331540.

39 Kawahara K, Maekawa T, Okabayashi K, et al: Video-assisted thoracoscopic esophagectomy for esophageal cancer. Surg Endosc 1999;13:218-223.

40 Osugi H, Takemura M, Higashino M, Takada N, Lee S, Kinoshita H: A comparison of video-assisted thoracoscopic oesophagectomy and radical lymph node dissection for squamous cell cancer of the oesophagus with open operation. Br J Surg 2003;90:108-113.

41 Osugi H, Takemura M, Higashino M, et al: Learning curve of video-assisted thoracoscopic esophagectomy and extensive lymphadenectomy for squamous cell cancer of the thoracic esophagus and results. Surg Endosc 2003;17:515-519.

42 Taguchi S, Osugi H, Higashino M, et al: Comparison of three-field esophagectomy for esophageal cancer incorporating open or thoracoscopic thoracotomy. Surg Endosc 2003; 17:1445-1450.

43 Smithers BM, Gotley DC, McEwan D, Martin I, Bessell J, Doyle L: Thoracoscopic mobilization of the esophagus. A 6 year experience. Surg Endosc 2001;15:176-182.

44 Luketich JD, Alvelo-Rivera M, Buenaventura PO, et al: Minimally invasive esophagectomy: outcomes in 222 patients. Ann Surg 2003;238:486-494.

45 Nguyen NT, Roberts P, Follette DM, Rivers $\mathrm{R}$, Wolfe BM: Thoracoscopic and laparoscopic esophagectomy for benign and malignant disease: lessons learned from 46 consecutive procedures. J Am Coll Surg 2003; 197:902-913.

46 Horgan S, Berger RA, Elli EF, Espat NJ: Robotic-assisted minimally invasive transhiatal esophagectomy. Am Surg 2003;69:624626.

47 Bodner JC, Zitt M, Ott H, et al: Robotic-assisted thoracoscopic surgery (RATS) for benign and malignant esophageal tumors. Ann Thorac Surg 2005;80:1202-1206.
48 Pierre AF, Luketich JD: Technique and role of minimally invasive esophagectomy for premalignant and malignant diseases of the esophagus. Surg Oncol Clin North Am 2002; 11:337-350.

49 Cuesta MA, van den Broek WT, van der Peet DL, Meijer S: Minimally invasive esophageal resection. Semin Laparosc Surg 2004;11: 147-160.

50 Malthaner RA, Wong RK, Rumble RB, Zuraw L: Neoadjuvant or adjuvant therapy for resectable esophageal cancer: a systematic review and meta-analysis. BMC Med 2004;2:35.

51 Kaklamanos IG, Walker GR, Ferry K, Franceschi D, Livingstone AS: Neoadjuvant treatment for resectable cancer of the esophagus and the gastroesophageal junction: a metaanalysis of randomized clinical trials. Ann Surg Oncol 2003;10:754-761.

52 Urschel JD, Vasan H, Blewett CJ: A metaanalysis of randomized controlled trials that compared neoadjuvant chemotherapy and surgery to surgery alone for resectable esophageal cancer. Am J Surg 2002;183:274-279.

53 Sugimachi K, Kitamura K, Baba K, Ikebe M, Morita M, Matsuda H, Kuwano H: Hyperthermia combined with chemotherapy and irradiation for patients with carcinoma of the oesophagus - a prospective randomized trial. Int J Hyperthermia 1992;8:289-295.

54 Fiorica F, Di Bona D, Schepis F, Licata A, Shahied L, Venturi A, Falchi AM, Craxi A, Camma C: Preoperative chemoradiotherapy for oesophageal cancer: a systematic review and meta-analysis. Gut 2004;53:925-930.

55 Urschel JD, Vasan H: A meta-analysis of randomized controlled trials that compared neoadjuvant chemoradiation and surgery to surgery alone for resectable esophageal cancer. Am J Surg 2003;185:538-543.

56 Greer SE, Goodney PP, Sutton JE, Birkmeyer JD: Neoadjuvant chemoradiotherapy for esophageal carcinoma: a meta-analysis. Surgery 2005;137:172-177.

57 Urba SG, Orringer MB, Turrisi A, Iannettoni M, Forastiere A, Strawderman M: Randomized trial of preoperative chemoradiation versus surgery alone in patients with locoregional esophageal carcinoma. J Clin Oncol 2001;19:305-313.

-58 Bosset JF, Gignoux M, Triboulet JP, Tiret E, Mantion G, Elias D, Lozach P, Ollier JC, Pavy JJ, Mercier M, Sahmoud T: Chemoradiotherapy followed by surgery compared with surgery alone in squamous-cell cancer of the esophagus. N Engl J Med 1997;337:161-167.

59 Le Prise E, Etienne PL, Meunier B, Maddern G, Ben Hassel M, Gedouin D, Boutin D, Campion JP, Launois B: A randomized study of chemotherapy, radiation therapy, and surgery versus surgery for localized squamous cell carcinoma of the esophagus. Cancer 1994;73:1779-1784. 
60 Apinop C, Puttisak P, Preecha N: A prospective study of combined therapy in esophageal cancer. Hepatogastroenterology 1994;41: 391-393.

-61 Nygaard K, Hagen S, Hansen HS, Hatlevoll R, Hultborn R, Jakobsen A, Mantyla M, Modig H, Munck-Wikland E, Rosengren B, et al: Pre-operative radiotherapy prolongs survival in operable esophageal carcinoma: a randomized, multicenter study of pre-operative radiotherapy and chemotherapy. The second Scandinavian trial in esophageal cancer. World J Surg 1992;16:1104-1110.

62 Walsh TN, Noonan N, Hollywood D, Kelly A, Keeling N, Hennessy TP: A comparison of multimodal therapy and surgery for esophageal adenocarcinoma. N Engl J Med 1996; 335:462-467.

63 Burmeister BH, Smithers BM, Gebski V, Fitzgerald L, Simes RJ, Devitt P, Ackland S, Gotley DC, Joseph D, Millar J, North J, Walpole ET, Denham JW: Surgery alone versus chemoradiotherapy followed by surgery for resectable cancer of the oesophagus: a randomised controlled phase III trial. Lancet Oncol 2005;6:659-668.

-64 Ando N, Iizuka T, Ide H, Ishida K, Shinoda M, Nishimaki T, Takiyama W, Watanabe H, Isono K, Aoyama N, Makuuchi H, Tanaka O, Yamana H, Ikeuchi S, Kabuto T, Nagai K, Shimada Y, Kinjo Y, Fukuda H: Surgery plus chemotherapy compared with surgery alone for localized squamous cell carcinoma of the thoracic esophagus: a Japan Clinical Oncology Group Study - JCOG9204. J Clin Oncol 2003;21:4592-4596.

65 Teniere P, Hay JM, Fingerhut A, Fagniez PL: Postoperative radiation therapy does not increase survival after curative resection for squamous cell carcinoma of the middle and lower esophagus as shown by a multicenter controlled trial. French University Association for Surgical Research. Surg Gynecol Obstet 1991;173:123-130.

-66 Fok M, Sham JS, Choy D, Cheng SW, Wong J: Postoperative radiotherapy for carcinoma of the esophagus: a prospective, randomized controlled study. Surgery 1993;113:138-147.

-67 Zieren HU, Muller JM, Jacobi CA, Pichlmaier H, Muller RP, Staar S: Adjuvant postoperative radiation therapy after curative resection of squamous cell carcinoma of the thoracic esophagus: a prospective randomized study. World J Surg 1995;19:444-449.
68 Xiao ZF, Yang ZY, Liang J, Miao YJ, Wang M, Yin WB, Gu XZ, Zhang de C, Zhang RG, Wang LJ: Value of radiotherapy after radical surgery for esophageal carcinoma: a report of 495 patients. Ann Thorac Surg 2003;75: 331-336.

69 Hironaka S, Ohtsu A, Boku N, Muto M, Nagashima F, Saito $H$, Yoshida S, Nishimura M, Haruno M, Ishikura S, Ogino T, Yamamoto S, Ochiai A: Nonrandomized comparison between definitive chemoradiotherapy and radical surgery in patients with $\mathrm{T}(2-$ 3) $\mathrm{N}$ (any) $\mathrm{M}(0)$ squamous cell carcinoma of the esophagus. Int J Radiat Oncol Biol Phys 2003;57:425-433.

-70 Cooper JS, Guo MD, Herskovic A, Macdonald JS, Martenson JA Jr, Al-Sarraf M, Byhardt R, Russell AH, Beitler JJ, Spencer S, Asbell SO, Graham MV, Leichman LL: Chemoradiotherapy of locally advanced esophageal cancer. Long-term follow-up of a prospective randomized trial (RTOG 85-01). Radiation Therapy Oncology Group. JAMA 1999;281:1623-1627.

71 Herskovic A, Martz K, al-Sarraf M, Leichman L, Brindle J, Vaitkevicius V, Cooper J, Byhardt R, Daivis L, Emami B: Combined chemotherapy and radiotherapy compared with radiotherapy alone in patients with cancer of the esophagus. N Engl J Med 1992; 326:1593-1598.

72 Geh JI, Crellin AM, Glynne-Jones R: Preoperative (neoadjuvant) chemoradiotherapy in oesophageal cancer. Br J Surg 2001;88:338356.

73 Adelstein DJ, Rice TW, Becker M, Larto MA, Kirby TJ, Koda A, Tefft M, Zuccaro G: Use of concurrent chemotherapy, accelerated fractionation radiation, and surgery for patients with esophageal carcinoma. Cancer 1997;80: 1011-1020.

74 Minsky BD, Pajak TF, Ginsberg RJ, Pisansky TM, Martenson J, Komaki R, Okawara G, Rosenthal SA, Kelsen DP: INT 0123 (Radiation Therapy Oncology Group 94-05) phase III trial of combined-modality therapy for esophageal cancer: highdose versus standard-dose radiation therapy. J Clin Oncol 2002;20:1167-1174.

75 Urba S G, Orringer M B, Perez-Tamayo C, Bromberg J, Forastiere A: Concurrent preoperative chemotherapy and radiation therapy in localized esophageal adenocarcinoma. Cancer 1992;69:285-291.

-76 Stahl M, Wilke H, Fink U, Stuschke M, Walz MK, Siewert JR, Molls M, Fett W, Makoski HB, Breuer N, Schmidt U, Niebel W, Sack H, Eigler FW, Seeber S: Combined preoperative chemotherapy and radiotherapy in patients with locally advanced esophageal cancer. Interim analysis of a phase II trial. J Clin Oncol 1996;14:829-837.
7 Chidel MA, Rice TW, Adelstein DJ, Kupelian PA, Suh JH, Becker M: Resectable esophageal carcinoma: local control with neoadjuvant chemotherapy and radiation therapy. Radiology 1999;213:67-72.

78 Bartels HE, Stein HJ, Siewert JR: Tracheobronchial lesions following oesophagectomy: prevalence, predisposing factors and outcome. Br J Surg 1998;85:403-406.

79 Keller SM, Ryan LM, Coia LR, Dang P, Vaught DJ, Diggs C, Weiner LM, Benson AB: High dose chemoradiotherapy followed by esophagectomy for adenocarcinoma of the esophagus and gastroesophageal junction: results of a phase II study of the Eastern Cooperative Oncology Group. Cancer 1998;83: 1908-1916.

80 Swisher SG, Wynn P, Putnam JB, Mosheim MB, Correa AM, Komaki RR, Ajani JA, Smythe WR, Vaporciyan AA, Roth JA, Walsh GL: Salvage esophagectomy for recurrent tumors after definitive chemotherapy and radiotherapy. J Thorac Cardiovasc Surg 2002; 123:175-183.

81 Urschel JD, Sellke FW: Complications of salvage esophagectomy. Med Sci Monit 2003;9: RA173-RA180.

82 Ferguson MK, Durkin AE: Preoperative prediction of the risk of pulmonary complications after esophagectomy for cancer. J Thorac Cardiovasc Surg 2002;123:661-669.

-83 Tabira Y, Okuma T, Kondo K, Yoshioka M, Mori T, Tanaka M, Nakano K, Kitamura N: Does neoadjuvant chemotherapy for carcinoma in the thoracic esophagus increase postoperative morbidity? Jpn J Thorac Cardiovasc Surg 1999;47:361-367.

84 Stein HJ, Brucher BL, Sendler A, Siewert JR: Esophageal cancer: patient evaluation and pretreatment staging. Surg Oncol 2001;10: 103-111.

85 Nagawa H, Kobori O, Muto T: Prediction of pulmonary complications after transthoracic oesophagectomy. Br J Surg 1994;81:860862 .

86 Nakamura T, Hayashi K, Ota M, Eguchi R, Ide H, Takasaki K, Mitsuhashi N: Salvage esophagectomy after definitive chemotherapy and radiotherapy for advanced esophageal cancer. Am J Surg 2004;188:261-266.

87 Law SY, Fok M, Wong J: Risk analysis of squamous cell carcinoma of the esophagus. World J Surg 1994;18:339-346. 